\title{
COMPRESSIVE STRENGTH OF HIGH PERFORMANCE CONCRETE USING GRANITE POWDER AS FINE AGGREGATE
}

\author{
Raghavendra $\mathbf{R}^{1}$, Sharada. S. A ${ }^{2}$, G. Ravindra. M. $\mathbf{V}^{3}$ \\ ${ }^{1}$ PG Student, Dept. of Civil Engineering, S.J.C. Institute of Technology, Chickaballapura - 562101, India \\ ${ }^{2}$ Asst. Professor, Dept. of Civil Engineering, S.J.C. Institute of Technology, Chickaballapura - 562101, India \\ ${ }^{2}$ Asst. Professor, Dept. of Civil Engineering, S.J.C. Institute of Technology, Chickaballapura - 562101, India
}

\begin{abstract}
The concrete is being used as $2^{\text {nd }}$ most essential material in the world and most of the companies are in need of economical concrete by replacing cement by cementitious material. This papers show the preparation of concrete using granite powder(brought from muddenahally, Chickaballapur) as a partial fine aggregates at a rate of 0\%, 5\%, 10\%, 15\%, 20\% and 25\% and cement is replaced using $10 \%$ fly ash, $10 \%$ GGBS, $7.5 \%$ silica fumes and $0.9 \%$ super plasticizer used too. The beams of size

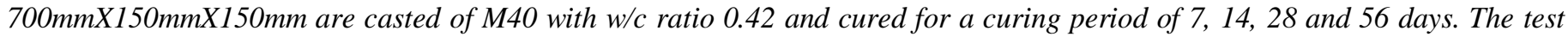
results shows increase in flexure strength till $20 \%$ of granite powder replacement and rest are equal to normal concrete. Thus, Granite Powder acts as a best replacement to natural sand till $25 \%$.
\end{abstract}

Keywords: GP-Granite Powder, cementitious material, flexure strength, HPC- high performance concrete, GGBS, FlyAsh ****

\section{INTRODUCTION}

The Normal Concrete is one of the old forms been used to build this world but now a new word came to existence saying High Performance Concrete. This HPC has all properties enhanced due to usage of cementitious material and now granite powder. This granite is the strongest of all material which is used for construction and now this is used for concrete in the form of powder as a partial replacement for natural sand.

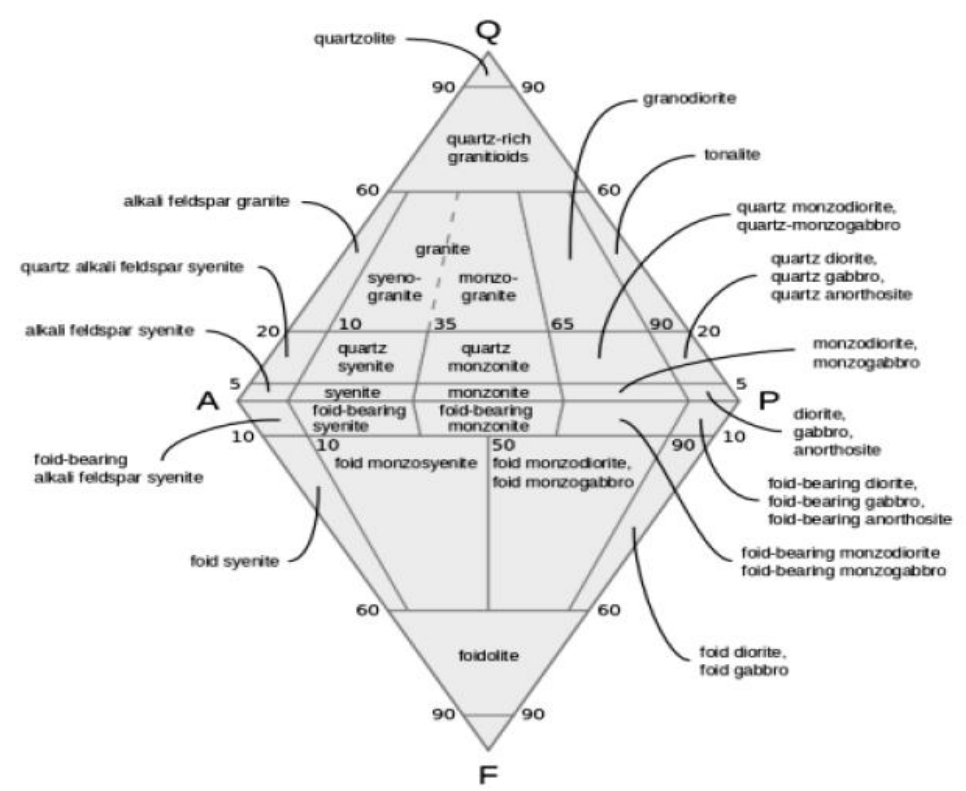

Fig 1: Plutonic rock showing quantity of granite

The conventional concrete is converted to HighPerformance Concrete by the use of chemical and mineral admixtures which plays a vital role in improving the characteristics like workability, strength parameters and many more. The admixtures added to cement concrete as a partial replacement along with super plasticizer as a water reducer to get the high performance. The usual mineral admixtures used are Fly-Ash, Silica Fumes, GGBS, and a small part of Rheo-build1125 as a Super Plasticizer for high performance. 
Based on the former experimental analysis, in this current work 10\% Fly Ash, 10\% GGBS, 7.5\% Silica Fumes and $0.9 \%$ Super Plasticizer has been used to generate high performance concrete using Granite Powder as partial replacement of Natural Sand with a following percentages that is $0 \%, 5 \%, 10 \%, 15 \%, 20 \%$ and $25 \%$. which are named as follows GP0, GP5, GP10, GP15, GP20 and GP25 respectively.

\section{LITERATURE REVIEW}

\section{Kanmalai Williams C, Partheeban P, Felix Kala}

This paper reports the results of an experimental study on the high performance concrete made with granite powder as fine aggregate. The percentage of granite powder added by weight a range viz. $0,25,50,75$ and $100 \%$ as a replacement of sand used in concrete and cement was replaced with $7.5 \%$ Silica fume, $10 \%$ fly ash, $10 \%$ slag and $1 \%$ super plasticizer. The effects of curing temperature at $32 \mathrm{C}$ and 0.40 water-to-binder (w/b) ratio for $1,7,14,28,56$ and 90 days on compressive strength, split tensile strength, modulus of elasticity, drying shrinkage and water penetration of concrete were studied. Experimental results indicate that the increase in the proportions of granite powder resulted in a decrease in the compressive strength of concrete. The overall test performance revealed that granite powder can be utilized as a partial replacement of natural sand in high performance concrete.

\section{MATERIAL USED}

A. Cement: Ordinary Portland Cement Birla Super of grade 43 was used for work. It was dry, clean and free from lumps and stored in a dry place and stacked very close to each other to avoid air circulation.

B. Silica Fumes: The Silica Fumes used for this work was bought from Rajaji Nagar Industrial Colony and it was white coloured and in powder form and $7.5 \%$ of cement was used. This helps in w/c ratio reduction and increase strength of concrete in hardened state.

C. Fly Ash: The Fly Ash which is a bi-product obtained from the gases of burning coal during the production of electricity. It was brought from Shakti Nagar Thermal Power Station, Raichur. It was light grey in colour and finest powder forms same as cement and considered as a best replacement. In this current work $10 \%$ to the weight of cement was used.

D. GGBS: Ground Granulated Blast furnace Slag. The slag collected on the grounds which are granulated well is called as GGBS and in the current work $10 \%$ slag was considered along with other admixtures as a replacement of cement.

E. Super Plasticizers: Rheo-build 1125 was used in current work which is Reddish Brown Liquid used at rate of $0.9 \%$ of cementitious material and reduces water upto $25 \%$.
F. Fine Aggregate: Natural Sand which is locally available was used which was having a fineness modulus 3.26 and conforming zone II with Specific Gravity 2.52 and water absorption $1.03 \%$.

G. Granite Powder: Granite Powder brought from Muddenahally, Chickaballapur used in this current work as partial replacement for fine aggregate having specific gravity 2.55 , water absorption $1.15 \%$, and fineness modulus 4.23 conforming Zone I.

H. Coarse Aggregate: The coarse aggregates were brought from Bharathi Crushers, Muddenahally, Chickaballapur. $20 \mathrm{~mm}$ downsize were used in this current work having specific gravity 2.65 and water absorption $0.45 \%$.

I. Water: The locally available portable water was used for mixing as well as curing which was clean

\section{MIX DEIGN}

The following table showing the mix design for the current project work. C-cement, F-fly ash, G-GGBS, SF-silica fumes, FA- fine aggregates, GP-granite powder, CA- coarse aggregate, $\mathrm{W}$-water, $\mathrm{SP}$ - super plasticizer (ALL in $\mathrm{kg} / \mathrm{m}^{3}$ )

Table 1: Mix Design Values.

\begin{tabular}{|l|l|l|l|l|l|l|l|l|l|}
\hline Name & C & F & G & SF & SP & FA & GP & CA & W \\
\hline GP0 & 410 & - & - & - & - & 735.3 & - & 1043.7 & 172 \\
\hline GP5 & 297.2 & 41 & 41 & 31 & 3.7 & 698.6 & 36.7 & 1043.7 & 172 \\
\hline GP10 & 297.2 & 41 & 41 & 31 & 3.7 & 661.2 & 73.5 & 1043.7 & 172 \\
\hline GP15 & 297.2 & 41 & 41 & 31 & 3.7 & 625.1 & 110.3 & 1043.7 & 172 \\
\hline GP20 & 297.2 & 41 & 41 & 31 & 3.7 & 588.3 & 147.1 & 1043.7 & 172 \\
\hline GP25 & 297.2 & 41 & 41 & 31 & 3.7 & 551.5 & 183.8 & 1043.7 & 172 \\
\hline
\end{tabular}

\section{MIXING PROCEDURE}

The general procedure of mixing concrete is same followed here in this project too. First the weigh all ingredients of concrete that is cement, fine aggregates, coarse aggregates, water and fly ash, GGBS, silica fumes, granite powder and super plasticizer for HPC. The coarse aggregate goes first in to the mixer and following that the fine aggregates, granite powder, mineral admixtures and water. The super plasticizer can be added while mixing or diluted in water as well. This goes the simple mixing procedure for the required $\mathrm{CC}$ and HPC.

\section{TESTS ON FRESH CONCRETE}

Table 2: Slump Values of concrete with varying GP\%

\begin{tabular}{|l|c|c|c|c|c|c|}
\hline $\begin{array}{l}\text { Name of the } \\
\text { test }\end{array}$ & GP0 & GP 5 & GP 10 & GP 15 & GP 20 & GP25 \\
\hline $\begin{array}{l}\text { Slump value } \\
(\mathrm{mm})\end{array}$ & 85 & 76 & 74 & 74 & 72 & 70 \\
\hline
\end{tabular}




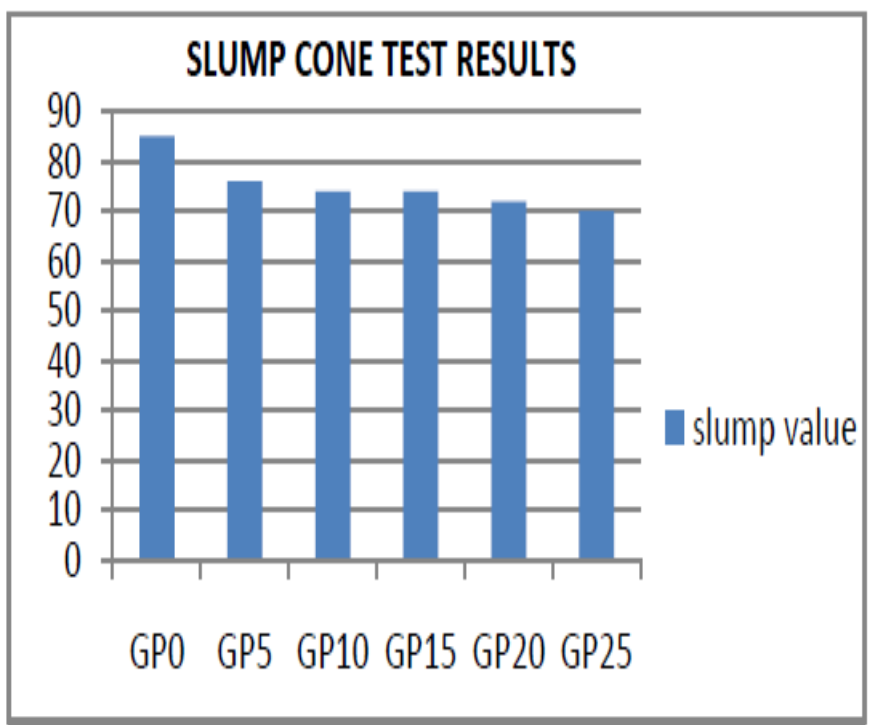

Fig 2: Graphical Representation of Slump Values

\section{TESTS ON HARDENED CONCRETE}

The compressive strength gives the capability of the concrete to sustain the loads by preparing blocks which will be tested using compression testing machine. The data presented show that the compressive strength of all the granite powder concrete was higher closer to that of reference mix (GP0).

Table 3: Compression Strength of concrete with varying GP\%

\begin{tabular}{|c|c|c|c|}
\hline \multirow{2}{*}{ Mix Designation } & \multicolumn{3}{|c|}{$\begin{array}{c}\text { Compressive strength in N/mm } \\
\text { period in days }\end{array}$} \\
\cline { 2 - 4 } & 7 Days & 14 days & 28 Days \\
\hline GP0 & 21 & 26 & 40 \\
\hline GP5 & 25 & 30.2 & 45.57 \\
\hline GP10 & 29.3 & 33.5 & 47 \\
\hline GP15 & 29 & 39 & 50.12 \\
\hline GP20 & 26 & 37 & 48 \\
\hline GP25 & 22 & 28 & 38 \\
\hline
\end{tabular}

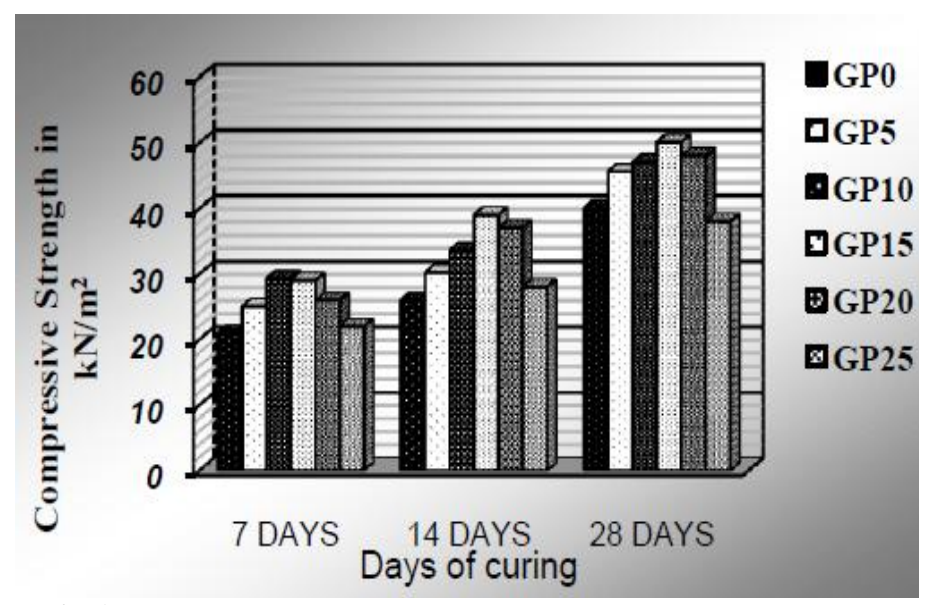

Fig 3: Graphical Representation of compressive strength with varying GP\%

\section{CONCLUSION}

- $\quad$ Compressive Strength of HPC shows increasing trend till $15 \%$ increment of Granite powder and again it was very near to the conventional concrete.

- The workability of concrete is good even after addition of the granite powder as replacement into concrete.

- The current experimental work shows that the strength properties of the concrete could be enhanced by utilization of granite powder in the place of river sand, granite powder in concrete are the best choice, where they are available.

Hence the granite aggregates can be considered as an alternative for fine aggregates (river sand).

\section{ACKNOWLEDGMENTS}

I acknowledge my regards to the Dept. of Civil Engg, S.J.C.INSTITUTE OF TECHNOLOGY, Chickballapur, for their constant supervision during my thesis work. I would also thank Shakthi Nagar Thermal Power Plant Raichur, JSW Bangalore and Bharathi Crushers Muddenahally Chickballapur for sponsoring and encouraging me by providing materials used in my work.

\section{REFERENCES}

[1]. Dr. G. Prince Arulraj, Mr. A .Adin and Mr. T. Suresh Kannan "Granite Powder Concrete" Department of Civil Engineering, SNS College of Technology, Coimbatore, Vol.3, No.1, February 2013.

[2]. Manasseh JOEL "Use of Crushed Granite Fine as Replacement to River Sand in Concrete Production" Civil Engineering Department University of Agriculture Nigeria, Issue 17, p. 85-96, July-December 2010.

[3]. T. Felixkala and P. "Granite Powder Concrete" Partheeban, Dept. of Civil Engg, Sathyabama University, Chennai Vol. 3 No. 3 (Mar 2010).

[4]. Felixkala T and Sethuraman V.S "Shrinkage Properties of HPC using Granite Powder as Fine Aggregate", Volume2, Issue-3, February 2013.

[5]. Rafat Siddique, Department of Civil Engineering, Thapar " Effect of fine aggregate replacement with Class F fly ash on the mechanical properties of concrete" Institute of Engineering and Technology, Deemed University, Patiala, Received 28 February 2002; accepted 16 September 2002.

[6]. Kanmalai Williams C. and Partheeban P "Mechanical Properties of High Performance Concrete Incorporating Granite Powder as Fine Aggregate" Felix Kala T, Department of Civil Engineering, Vol.2, No.1, July 2008.

[7]. Dr. T. Felix Kala 1 "Effect of Granite Powder on Strength Properties of Concrete" , Department of Civil Engineering, Dr. M.G.R. Educational and Research Institute University, Maduravoyal, Chennai, Vol.2, Issue 12 Pp 36-50 (May 2013) .

[8]. IS: 10262:2009, "Recommended Guidelines for Concrete Mix Design" Indian Standard Institution, New Delhi. 